\author{
В.И. Голик ${ }^{1}$, В.И. Комащенко ${ }^{2}$, В.С. Моркун ${ }^{3}$, \\ Н.В. Моркун ${ }^{3}$, С.Н. Грищенко ${ }^{3}$ \\ ${ }^{1}$ Северо-Кавказский государственный технологический университет, \\ ул. Николаева, 44, Владикавказ, 362021, Россия, v.i.golik@mail.ru \\ ${ }^{2}$ Российский государственный университет нефти и газа (национальный исследовательский университет) \\ имени И.М. Губкина, Ленинский проспект, корп. 1, д. 65, Москва, 119991, Россия, \\ komashchenko@inbox.ru \\ ${ }^{3}$ гВУЗ «Криворожский национальный университет», \\ ул. Виталия Матусевича, 11, Кривой Рог, 50027, Украина, \\ +380 67976 2925, s-grischenko@ukr.net

\section{К ПРОБЛЕМЕ ЭНЕРГОСБЕРЕЖЕНИЯ В ГОРНОМ ПРОИЗВОДСТВЕ}

Введение. Горное производство является весьма энергоемкой отраслью из-за напряженности режимов технологических процессов, в которых расход энергии оптимизируется путем технической модернизации, например, процесса приготовления твердеющих смесей с обработкой компонентов смеси до нужного уровня крупности и активности.

Проблематика. Минимизация затрат энергии при увеличении объема производства, повышение энергоэффективности технологических процессов и снижение затрат на энергообспечение формирует самостоятельную проблему горного производства, определяющую конкурентоспособность горного предприятия.

Цель. Определение влияния процессов дезинтеграции и повышения активности рудных минералов на электропотребление горного предприятия.

Материалы и методы. Эффективность механоактивации определяется разницей прочности бетонов, приготовленных на основе базовых и активированных вяжущих. Рациональная комбинация технологий находится как оптимум решения с учетом переменных факторов, в том числе и энергозатрат. Область оптимальных значений вяжущих находится совместным решением уравнений, описывающих полученные закономерности.

Результаты. Приведены результаты промышленного эксперимента по замене вяжущих компонентов бетонных смесей активированными доменными шлаками. Определены количественные значения и закономерности расхода электроэнергии на активацию компонентов твердеющих смесей. Полученные данные использованы для моделирования процессов подготовки смеси в условиях одного из предприятий Норильска. Установлены общие закономерности полезного действия механической активации. Сформулирована концепция и алгоритм рационализации энергопользования в процессах активации отходов горного производства.

Выводы. В связи с демографическими факторами развития горное производство будет увеличивать энергоемкость производственных процессов. При переходе на отработку месторождений подземным способом расход энергии на приготовление твердеющих смесей возрастет. Особенную актуальность приобретает направление полезного расходования энергии в электроемких процессах. Оптимизация расхода энергии в определенных условиях способствует компенсации затрат на диверсификацию горного производства.

Ключевые слова: энергоэффективность, энергосбережение, горное производство, дезинтегратор, активация.

Использование энергетических ресурсов является одним из ключевых вопросов устойчи-

(С В.И. ГОЛИК, В.И. КОМАЩЕНКО, В.С. МОРКУН, Н.В. МОРКУН, С.Н. ГРИЩЕНКО, 2018 вого развития промышленности. Горное производство, отличающееся опережающим ростом энергопотребления по отношению к темпам роста промышленной продукции, является весьма энергоемкой отраслью [1-3]. 
Основным фактором, влияющим на электропотребление, является производственная мощность. Расход электроэнергии определяется режимами работы горного оборудования. Электропотребление на предприятиях горной промышленности отличается неравномерностью графика производства и потребления электроэнергии, необходимостью бесперебойного электроснабжения, обеспечением качества электроэнергии и учета ее в соответствии с заданным режимом работы электроустановки, а также особенностями электроприемников.

Потребление электроэнергии в горной промышленности зависит от многих, не всегда учитываемых при планировании горных работ, факторов. В практике передовых предприятий интенсификация производственных процессов и улучшение их организации обеспечивают экономию электроэнергии, поэтому удельный расход электроэнергии может выполнять роль показателя технологического уровня горного производства [4-6].

Одним из наиболее энергонапряженных процессов горного производства является приготовление твердеющих смесей, в котором львиную долю занимает операция измельчения компонентов смеси до нужного уровня крупности и активности.

По размерным характеристикам, таким как численность занятого персонала, выручка, потребление энергии и влияние на окружающую среду, добывающие предприятия регионов являются более мощными, чем другие предприятия отрасли. Выпуск продукции на одного занятого в регионах, добывающих минеральные ресурсы, выше среднего по стране на 32 \%. Недропользование, как один из самых мощных секторов экономики, отличается устойчивостью тенденции к росту воздействий внешней среды при невысоких темпах повышения производственной мощности.

В горном производстве увеличение производительности труда и производственной мощности достигается путем технической модернизации [7].
Использование меньшего количества энергии для обеспечения технологических процессов на производстве является целью многих исследований. В отличии от энергосбережения, направленного на уменьшение энергопотребления, энергоэффективность преследует иную цель - полезное расходование энергии.

Повышение энергоэффективности процесса является приоритетным фактором снижения производственных затрат и получения прибыли. Повышение энергоэффективности промышленного предприятия способствует экономическому росту, обеспечению благоприятной социально-бытовой и экологической обстановки, улучшению благосостояния работников.

В развитых странах энергосбережение является главной составляющей технологического проекта. Энергосбережение преследует цель сокращения расхода топливно-энергетических ресурсов. Минимизация затрат энергии при одном и том же или увеличенном объеме производства является целью научного прогресса. Повышение энергоэффективности процессов обеспечивается путем проведения мероприятий по энергосбережению, применением передовых технологий при потреблении и транспортировке энергоресурсов.

Повышение энергетической эффективности предприятий позволяет повысить не только конкурентоспособность продукции, но и конкурентоспособность всей страны.

Многочисленные исследования проблемы энергоэффективности сводятся к тому, что энергопотребление определяется корректностью режимов работы энергопотребителей в рамках применяемых технологий и активностью участвующих в процессах веществ [8-10].

Было замечено, что при обработке вещества быстро следующими друг за другом ударами (скорость удара 250 м/с), изменяются его технологические свойства.

Теория управления состоянием вещества путем активации в дезинтеграторе, с точки 
зрения расходования энергетических ресурсов, может найти применение в горном производстве с его высокими темпами энергопотребления и практически неисчерпаемыми запасами возможных к утилизации отходов добычи и обогащения, когда извлечение металлов из ранее теряемого минерального сырья может многократно окупить затраты на энергопотребление при осуществлении процессов.

Новое направление использования энергии вещества получило название «энергоинфузиология». Энергоинфузиология решает следующие задачи:

+ повышение эффективности активации веществ с комбинированием механических и параллельных им энергетических полей;

+ повышение устойчивости эффекта активации;

+ установление корреляции между активацией, физико-химическими и технологическими процессами.

Сверхзадачей управления электропотреблением на предприятиях горной промышленности является поддержание энергосберегающих проектов. Для оптимизации энергопотребления используются экспериментально полученные данные об энергонапряженности промышленных процессов [11-13].

Горное производство увеличивает энергоемкость своих систем одновременно с ростом производственной мощности добывающих и увеличением количества перерабатывающих предприятий, а также ужесточением режима работы их потребителей, особенно, в некомфортных для жизнедеятельности регионах. Этот процесс будет усиливаться по мере контрастности в равномерности пространственного размещения предприятий горного производства и увеличением потребления электроэнергии.

Увеличивается энергоемкость процессов в отдельных прорывных процессах горного производства, например, при приготовлении твердеющих смесей для управления состоянием рудовмещающих массивов и земной поверхности над ними.

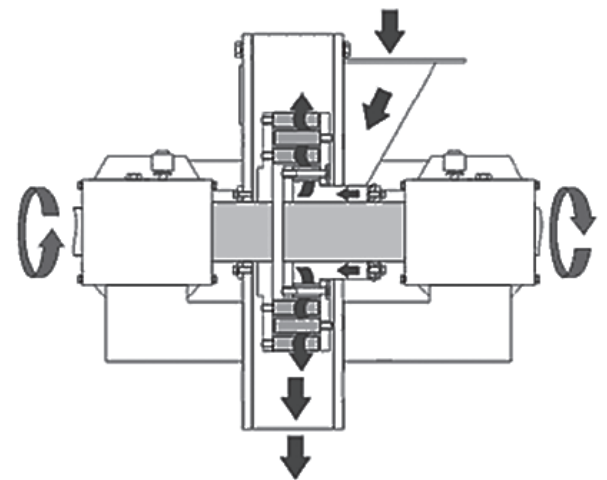

Puc. 1. Схема дезинтегратора (стрелками указаны направления вращения роторов двигателей)

Приобретает особую значимость направление полезного расходования полученной и распределенной между потребителями энергии в пределах предприятия.

Целью настоящего исследования является определение влияния процессов дезинтеграции с повышением активности рудных минералов на электропотребление в рамках горного предприятия. Дезинтегратор состоит из двух вращающихся в противоположные стороны роторов, насаженных на соосные валы (рис. 1).

Материал подвергается ударам пальцев, вращающихся со скоростью 500-1000 об./мин во встречных направлениях.

При обработке в веществе на вновь образованных поверхностях аккумулируется энергия, величина которой может достигать десятков процентов от всей затраченной на обработку энергии, например, для кремнезема эта величина составляет $30 \%$. Количество этой энергии в течении одного и того же времени обработки превышает количество энергии при обработке в мельнице.

Чтобы различать понятия механической активации в мельницах и в дезинтеграторе, наблюдаемый эффект называют активацией высокой механической энергией.

Накопленная энергия деформации реализуется в процессе измельчения материала и в последующих химических процессах. 


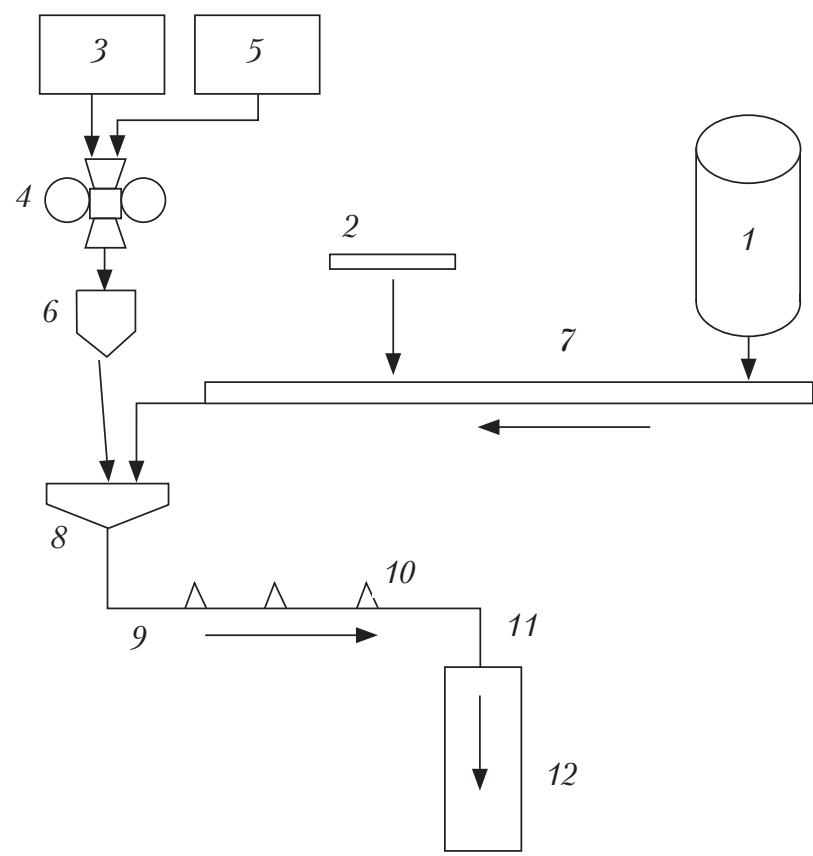

Puc. 2. Схема закладочного комплекса с дезинтегратором: 1 - вяжущие; 2 - падение инертных материалов; 3, 5 - добавки к вяжущему веществу; 4 - дезинтегратор; 6 - вибрационная мельница; $6,8-$ смесители; 7 - конвейер; 9 - вибродоставочный трубопровод; 10 - вибратор; 11 - закладочная скважина; 12 - закладываемая выработка

На месторождении «Шокпак» (Северный Казахстан) в течении 10 лет доменные шлаки активировали в промышленной установке ДУ-65 с целью снижения затрат на изготовление вяжущих цементов (рис. 2) [14].

Дезинтегратор обеспечивал выход активного класса доменных шлаков до 55 \%, а следовавшая за этим активация в вибромельнице увеличивала выход до 70 \%, что позволяло активированному шлаку конкурировать с цементом.

Применение активированной добавки из доменного шлака намного снижало расход цемента. Сравнение прочности смеси по истечении 28 дней при расходе 180 кг м $^{3}$ только одного цемента и 80 кг $/ \mathrm{m}^{3}$ цемента с добавкой 370 кг м $^{3}$ активированного шлака показало, что эквивалентом 1 кг цемента можно считать 4 кг активированных хвостов. За счет эффекта активации обработка в дезинтеграторе обеспечивает увеличение прочности на 25-30 \%, чем обработка в мельнице.

Базой для сравнения служила тонкость помола или выход фракций крупностью 0,074 мм, получаемых при размоле в шаровой мельнице. Тонкость помола в дезинтеграторе при выходе такой фракций в количестве 40-60 \% обеспечивалась при обработке доменного гранулированного шлака с суммарной встречной скоростью около $100 \mathrm{~m} / \mathrm{c}$ [15].

Эффективность механоактивации определяется разницей прочности бетонов из веществ, приготовленных на основе вяжущих составов, активированных в дезинтеграторе. Эти показатели принимаются как базисные.

Так, состав 1 м $^{3}$ смеси с расходом цемента 150 кг был заменен сложным вяжущим с цементом и активированным шлаком. При $K=0,9$ весовое количество сложного вяжущего составило 163 кг $/ \mathrm{m}^{3}$.

Рациональная комбинация отходов находится как оптимум решения с учетом переменных факторов, в том числе прочности, стоимости и транспортабельности по критерию максимального объема утилизации отходов. Совместное решение уравнений определяет область оптимальных значений природосберегающих технологий разработки.

Расход энергии, затрачиваемой на активацию веществ в дезинтеграторе, составил от 5 до 30 кВт • ч/т.

На первом этапе на холостом ходу дезинтегратора сила тока электродвигателя наружного ротора была (2 и 4 круга) в среднем составляла $I_{(2-4)}=168 \mathrm{~A}$, а внутреннего ротора (1 и 3 круги) - в среднем $I_{0(1-3)}=126$ А. Во время обработки сила тока соответственно составила $I_{(2-4)}=564 \mathrm{~A} ; I_{(1-3)}=271 \mathrm{~A}$.

На втором этапе на холостом ходу сила тока такая же, что и на первом этапе, а во время обработки она соответственно составляет $I_{(2-4)}=$ $=564 \mathrm{~A} ; I_{(1-3)}=336 \mathrm{~A}$.

Общая потребляемая мощность электродвигателя $(N$, кВт): 


$$
N=I U \cdot \sqrt{3} \cos \gamma
$$

где $I$ - сила тока, А; $U$ - напряжение тока, В; $\cos$ - коэффициент использования активной мощности электродвигателя.

На холостом ходу $\cos \gamma=0,81$ и потребляемая мощность электродвигателей будет следующей:

$$
N_{(2-4)}=89,6 \text { кВт; } N_{(1-3)}=67,2 \text { кВт. }
$$

Общая потребляемая мощность на холостом ходу составляет

$$
N_{0}=89,6+67,2=156,8 \text { кВт. }
$$

При обработке шлака в дезинтеграторе $\cos \gamma=$ $=0,92$ и потребляемая мощность:

на первом этапе $N_{(2-4)}=267$ кВт, $N_{(1-3)}=164$ кВт; на втором этапе $N_{(2-4)}=341,5 \kappa \mathrm{Bт}, N_{(1-3)}=$ $=203,5 \kappa$ К

Общая потребляемая мощность составила: на первом этапе $N_{1}=267+164=431$ кВт; на втором этапе $N_{2}=341,5+203,5=545$ кВт. Учитывая, что при обработке шлака в дезинтеграторной установке ДУ-65 производительность $Q_{1}=28,3$ т/ч и $Q_{2}=41,1 \mathrm{~T} /$, расход энергии можно вычислить по формуле:

на первом этапе:

$$
\begin{gathered}
E_{\text {нетто }(2-4)}=\frac{N_{(2-4)}-N_{0(2-4)}}{Q_{1}}, \mathrm{\kappa BT} \cdot \mathrm{ч} / \mathrm{T}, \\
E_{\text {брутто }(2-4)}=\frac{N_{(2-4)}}{Q_{1}}, \mathrm{\kappa BT} \cdot \mathrm{ч} / \mathrm{T},
\end{gathered}
$$

где $E_{\text {брутто(2-4) }}-$ брутто-расход электроэнергии наружного ротора, кВт · ч/т; $N_{(2-4)}-$ потребляемая мощность наружного ротора, кВт; $Q_{1}-$ производительность, т/ч.

$$
\begin{gathered}
E_{\text {брутто }(2-4)}=\frac{267}{28,3}=9,4, \mathrm{\kappa} \mathrm{BT} \cdot \mathrm{ч} / \mathrm{T}, \\
E_{\text {брутто }(1-3)}=\frac{164}{28,3}=5,8, \mathrm{\kappa} \mathrm{BT} \cdot \mathrm{ч} / \mathrm{T}, \\
E_{\text {нетто (2-4) }}=\frac{N_{(2-4)}-N_{0(2-4)}}{Q_{1}}, \mathrm{\kappa} \mathrm{BT} \cdot \mathrm{ч} / \mathrm{T},
\end{gathered}
$$

где $E_{\text {нетто(2-4) }}-$ нетто-расход энергии наружного ротора, кВт $\cdot$ ч/т; $N_{0(2-4)}-$ потребляемая мощность наружного ротора при обработке, кВт; $N_{0(2-4)}$ - потребляемая мощность наружного ротора на холостом ходу, кВт; $Q_{1}-$ производительность, т/час.

$$
\begin{aligned}
& E_{\text {нетто }(2-4)}=\frac{267-89,6}{28,3}=6,3, \kappa \mathrm{KT} \cdot \mathrm{ч} / \mathrm{T}, \\
& E_{\text {нетто }(2-4)}=\frac{164-67,2}{28,3}=3,4, \mathrm{\kappa BT} \cdot \mathrm{ч} / \mathrm{T},
\end{aligned}
$$

на втором этапе:

$$
\begin{gathered}
E_{\text {брутто (2-4) }}=\frac{341,5}{41,1}=9,4, \mathrm{\kappa BT} \cdot \mathrm{ч} / \mathrm{T}, \\
E_{\text {брутто (1-3) }}=\frac{203,5}{41,1}=5,0, \mathrm{\kappa BT} \cdot \mathrm{ч} / \mathrm{T}, \\
E_{\text {нетто }(2-4)}=\frac{341,5-89,6}{41,1}=6,1, \mathrm{\kappa BT} \cdot \mathrm{ч} / \mathrm{T}, \\
E_{\text {нетто }(1-3)}=\frac{203,5-67,2}{41,1}=3,3, \kappa \mathrm{BT} \cdot \mathrm{ч} / \mathrm{T} .
\end{gathered}
$$

Для практического определения потребляемой роторами мощности целесообразно использовать формулы:

$$
\begin{aligned}
& N_{(1-3)}=N_{0(1-3)}+E_{\text {нетто(1-3) }} \cdot Q, \kappa \mathrm{BT} \cdot \text { ч } / \mathrm{T}, \\
& N_{(2-4)}=N_{0(2-4)}+E_{\text {нетто(2-4) }} \cdot Q, \kappa \mathrm{BT} \cdot \text { ч } / \mathrm{T} .
\end{aligned}
$$

Расчетная мощность электродвигателей дезинтегратора с четырехрядными роторами при обработке гранулированного шлака составит:

$$
\begin{aligned}
& 0,8 N_{(1-3)}=67+4 Q, \kappa \mathrm{BT} \cdot \mathrm{ч} / \mathrm{T}, \\
& 0,8 N_{(2-4)}=90+7 Q, \kappa \mathrm{BT} \cdot \mathrm{ч} / \mathrm{T} .
\end{aligned}
$$

Феномен активации высокой энергией при обработке в дезинтеграторе зафиксирован при обработке многих материалов, в том числе, тампонажные смеси, силикальцит, железная руда, вольфрамовые, медные и железорудные концентраты, вода, протеиновый концентрат и др.

Модернизация традиционных обогатительных процессов осуществляется за счет совмещения операций гидрометаллургической и химической переработки с использованием новых технологических процессов. Перспективным направлением является совмещенное 
во времени реагентное выщелачивание и механическая активация в дезинтеграторе.

Горно-технологической причиной увеличения количества некондиционного минерального сырья в хранилищах является преобладающая тенденция валовой выемки руд из недр в расчете на прогресс технологий их обогащения на поверхности, чего в действительности не происходит.

Возможности традиционных технологий обогащения ограничены конструкцией оборудования и использованием в процессах обогащения преимущественно одной - механической энергии. Повышение эффективности обогащения возможно при использовании иных видов энергии.

Возможности использования феномена активации в горном деле исследованы применительно к условиям конкретного предприятия «Норильский никель».

В состав твердеющей смеси, приготавливаемой на их закладочных комплексах, входят ангидрит, шлак и цемент. Ангидритовые фракции после дробления в молотковой дробилке подаются в мельницу, где измельчаются до такой степени, что крупностью менее 0,08 мм обладают до 30 \% переработанной массы, и используются в качестве не вяжущего, а инертного заполнителя.

Недостатком применяемой на комбинате технологии является использование компонентов твердеющей смеси без использования возможностей активации.

Ангидрит может замещать цемент при реализации его вяжущих способностей путем раскрытия рабочих поверхностей до 50 \% вещества крупности до 0,08 мм в дезинтеграторе, который помещается между мельницей и смесителем.

Указанные процессы протекают и при активации в дезинтеграторе шлаков и цемента. Гранулированный шлак электропечей без дробления после нерегулируемого измельчения в мельнице трудно транспортируется по закладочному трубопроводу. Активация цемента повышает его марку с М300 до М400.
В дезинтеграторе одновременно с процессами механической активации выщелачивается до 50-70 \% ценных компонентов. Примечательно, что активированные вещества обладают свойствами не только инертных заполнителей, но и вяжущих веществ, и могут замещать как цемент, так и ангидрит.

Применение в условиях ОАО «Норильский Никель» дезинтеграторов обеспечивает:

+ замену цемента ангидритом с уменьшением транспортных затрат;

+ сокращение расхода ангидрита при увеличении его активности;

+ уменьшение влияния конъюнктуры цен на компоненты смеси;

+ повышение транспортабельности твердеющей смеси по трубопроводу;

+ извлечение металлов из хвостов обогащения и металлургии;

+ оздоровление окружающей среды.

Ожидаемые технико-экономические результаты:

+ уменьшение затрат на приготовление твердеющих смесей на 20-30 \%;

+ уменьшение энергоемкости закладочных работ на 15-20\%;

+ утилизация до 50 \% хвостов обогащения и металлургии;

+ увеличение на 1-2 \% выпуска металлов. Закономерности полезного действия механической активации сводятся к следующему:

1. За счёт энергии, использованной при механической обработке вещества, в нем накапливается энергия особого вида. Под действием четырехсот миллионов ускорений свободного падения происходит структурное изменение состояния вещества с превращением работы в тепло.

2. Абсолютная температура обрабатываемого материала оказывает наибольшее влияние на коэффициент полезного действия процесса.

3. В процессе механической активации система подвергается резким скачкообразным изменениям нагрузки. Наибольшая кинетическая энергия достигается путём встречных ударов при больших скоростях. 
4. При совместной обработке взаимно реагирующих компонентов механическая энергия используется не только для механической активации компонентов реакции, но и на химические процессы.

5. В дезинтеграторе достигаются во много раз большие импульсные мощности и частоты, чем при обработке материала в шаровой или вибромельнице. Частицы материала получают большее количество энергии, чем при более длительной обработке в шаровой или вибромельнице.

Эффект дезинтеграции установлен и при дезинтеграторной обработке материалов в смежных отраслях с получением следующих количественных параметров качества:

+ активированную фосфоритную муку растения усваивают в разы лучше, чем муку, измельченную до таких же размеров в шаровой мельнице;

+ при помоле одного и того же клинкера в шаровой мельнице и в дезинтеграторе до одинаковой тонины в последнем случае получают портландцемент, прочность изделий из которого через 16 дней равна той, которая достигается измельченным в шаровой мельнице цементом, лишь на 28 день;

+ активация смесей для закрепления стенок глубоких буровых скважин при добыче нефти и газа позволяет повысить прочность бетона при растяжении до 5 раз;

+ активация буровых растворов позволяет на 20-25 \% повысить скорость бурения, сократить содержание твёрдой фазы в них в 2,02,5 раза, уменьшить износ бура;

+ активация силикальцита позволяет изготовить искусственный камень в 2 раза дешевле при уменьшении расхода энергии на $50 \%$;

+ активация стекольной смеси и шихты для производства огнеупоров более чем на $20{ }^{\circ} \mathrm{C}$ понижает температуру плавления или обжига, повышает скорость процесса в два раза и улучшает качество изделий;

+ активация железной руды позволяет более чем на $100{ }^{\circ} \mathrm{C}$ снизить температуру восста- новления металла за время на 20 \% меньшее по сравнению с рудой, измельченной до той же тонины в шаровой мельнице;

+ активация вольфрамовых концентратов увеличивает извлечение металла на 10 \% и на 15-20 \% уменьшает продолжительность гидротермической обработки;

+ обработка медных и железорудных концентратов совместно с вяжущим веществом увеличивает прочность окатышей на 25-35 \%;

+ обработка кремнезема в несколько раз увеличивает его адсорбционную способность;

+ обработка крахмалосодержащего сырья для спиртового производства на 20 \% увеличивает скорость сбраживания и повышает выход спирта;

+ обработка водонефтяных смесей на 5-7 \% повышает их калорийность, увеличивает эффективность работы двигателя и обеспечивает полное сгорание топлива;

+ активация питательной среды для выращивания микроорганизмов повышает скорость их роста на $15-25 \%$;

+ обработка отходов резины, стеклопластика, стекловолокна позволяет получить ценный порошковый продукт, используемый в качестве наполнителей для полимеров;

+ обработка комбикорма на десятки процентов улучшает качество продуктов, экономит энергию и снижает эксплуатационные расходы;

+ обработка протеинового концентрата увеличивает выход клеточного сока в 2 раза.

С целью установления влияния энергетической компоненты на вещество при активизации процессов извлечения металлов обработке подвергались хвосты обогатительной фабрики и руды полиметаллического месторождения Садонское (рис. 3).

Содержание свинца и цинка в объектах выщелачивания, \%:

+ хвосты обогащения: цинк - 0,95, свинец 0,84

+ руда: цинк - 3,2, свинец - 1,6.

Были выполнены эксперименты для хвостов или руды в таких режимах: 


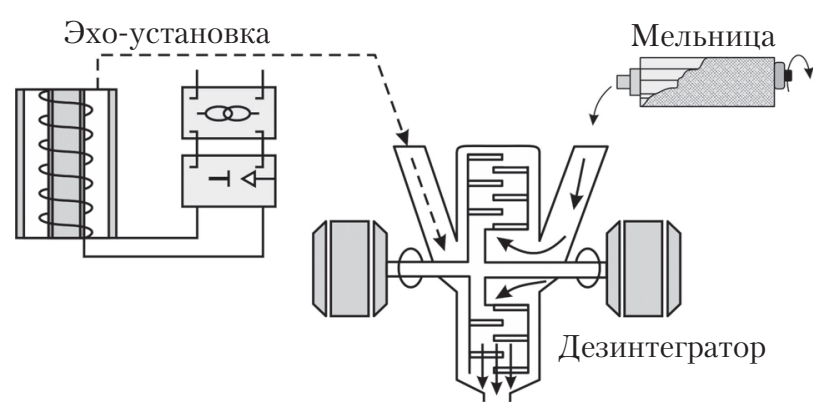

Puc. 3. Механохимическое выщелачивание минералов в дезинтеграторе

1 - агитационное выщелачивание;

2 - агитационное выщелачивание, активированных в сухом состоянии;

3 - выщелачивание в момент активации с растворами в дезинтеграторе;

4 - агитационное выщелачивание с предварительной активацией в дезинтеграторе с выщелачивающими растворами;

5 - выщелачивание в дезинтеграторе с неоднократным циклом.

Измерение энергетических показателей осуществлялось с помощью анализатора количества и качества электрической энергии AR-5.

При обработке 1 кг сухих хвостов (влажность 2,0 \%) с частицами размером менее 2,0 мм, подаче материала со скоростью 10 кг/ч и частоте вращения роторов дезинтегратора 200 Гц, был получен порошок с 93 \% содержанием фракции менее 0,1 мм. Ток двигателя вращения ротора составлял 8,5 A, температура хвостов увеличилась на $32{ }^{\circ} \mathrm{C}$.

При обработке 1 кг сухой руды (влажность 2,0 \%), предварительно измельченной до размера частиц менее 2,0 мм, подаче материала со скоростью 10 кг/ч и частоте вращения роторов дезинтегратора 200 Гц, получен порошок с 95,3 \% содержанием фракции менее 0,1 мм. Ток двигателя вращения ротора составлял 9,2 A, температура хвостов увеличилась на $37^{\circ} \mathrm{C}$.

При обработке 1 кг пульпы, полученной добавлением к 0,2 кг хвостов с размером частиц менее 2,0 мм выщелачивающего раствора (1,0 л) с содержанием хлорида натрия 100 г/л и серной кислоты 6 г/л, подаче пульпы со скоро- стью 10 кг/ч и частоте вращения роторов дезинтегратора 200 Гц, получен порошок с 92,7 \% содержанием фракции менее 0,1 мм. Ток двигателя вращения ротора составлял $8,1 \mathrm{~A}$, температура пульпы увеличилась на $22{ }^{\circ} \mathrm{C}$.

При обработке 1 кг пульпы, полученной добавлением к 0,2 кг руды с частицами менее 2,0 мм 1,0 л выщелачивающего раствора с содержанием хлорида натрия 100 г/л и серной кислоты 6 г/л, подаче пульпы со скоростью 10 кг/ч и частоте вращения роторов дезинтегратора 200 Гц, получен порошок с 92,1\% содержанием фракции менее 0,1 мм. Ток двигателя вращения ротора составлял 8,3 А, температура пульпы увеличилась на $26{ }^{\circ} \mathrm{C}$.

Дезинтеграторная технология получает развитие, в том числе, за счет совершенствования конструкции дезинтегратора. Например, помещая дезинтегратор на вибрирующую основу, создают дополнительное силовое поле, способствующее снижению расхода электроэнергии на процесс активации (рис. 4).

Во всех случаях, где, кроме активации, образуются новые вещества и протекают эндотермические реакции, электрическая энергия окупается в 3-30-кратном размере.

Установление закономерностей зависимости электропотребления для энергоемких установок и технологических переделов от производственных факторов необходимо для обоснования технологических процессов горного производства [16-18].

Пути реализации концепции рационализации энергопользования включают в себя этапы:

1. Путем анализа существующих представлений определяют пределы возможностей традиционных технологий обогащения, результатом которых являются хвосты, дальнейшее использование которых невозможно.

2. Опытным путем определяется возможность извлечения всех металлов из хвостов обогащения и металлургии до санитарных норм путем сочетания возможности одновременно химического обогащения и активации в дезинтеграторе. 


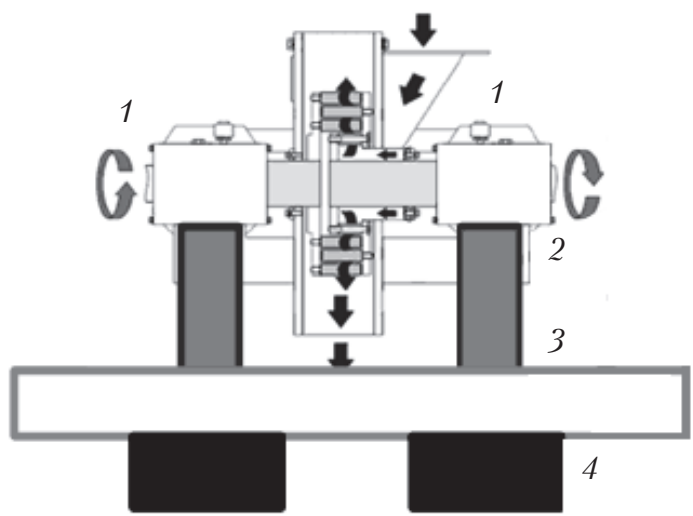

Puc. 4. Схема модернизации дезинтегратора: 1 - дезинтегратор; 2 - вибровозбудители; 3 - основание; 4 - виброизолирующие опоры

3. Исследуются факторы, определяющие показатели технологии выщелачивания металлов, в том числе, состав выщелачивающего раствора, соотношение Ж:Т (количество жидкого раствора и твердого выщелачиваемого материала) и время выщелачивания.

4. Исследуются возможности определения содержания всех извлекаемых металлов при их малой концентрации.

5. Исследуются возможности разделения металлов в продуктивном растворе.

6. Определяются возможности обеспечения прочности рабочих органов дезинтегратора.

7. По опасности химического загрязнения земель продуктами природного выщелачивания с учетом стадии существования предприятия горной промышленности и опасности самих технологий извлечения металлов оценивается компонент экологического ущерба окружающей среде.

8. Определяется эколого-экономическая эффективность производства металлов из отходов переработки как функция объединения инновационных методов с традиционными методами.

9. Оцениваются возможности внедрения результатов исследований в практическую и образовательную деятельность и их коммерциализация.
10. Осуществляется проектирование промышленной установки.

11. Строится промышленная установка.

12. Организуется предприятие по ликвидации отходов переработки руд.

Таким образом осуществляются новые подходы к решению проблемы энергопользования:

+ используется новый вид энергетического воздействия на минеральное сырье - активация;

+ в результате комбинирования механической и химической технологий возникает синергетический эффект, представляющий собой новые возможности для рационального использования энергии;

+ при традиционных способах обогащения из хвостов извлекается допускаемое технологическими возможностями количество полезных компонентов, остальные или остаются в первичных хвостах, или теряются во вторичных хвостах, тогда как предложенный проект позволяет извлекать из хвостов все металлы до фоновых для данных условий значений;

+ традиционные способы не позволяют ликвидировать хвостохранилища с доведением вторичных хвостов до экологической чистоты, а проектный подход решает эту проблему.

Изложенные особенности и закономерности энергопотребления при решении проблемы повышения энергоэффективности путем освоения новых технологических решений корреспондируют с результатами аналогичных исследований в развитых странах мира [19-22].

\section{Выводы}

Горное производство и впредь будет увеличивать энергоемкость с ростом производственной мощности добывающих и перерабатывающих предприятий и ужесточением режима работы их потребителей.

Будет возрастать значение специфических для горного производства факторов, в том 
числе, неравномерность производства и потребления электроэнергии, а также особенности электроприемников.

В связи с переходом на отработку месторождений подземным способом будет увеличиваться энергоемкость процессов приготовления твердеющих смесей с активацией их компонентов.

Кроме задач уменьшения энергопотребления при решении проблемы повышения энергоэффективности приобретает актуальность направление полезного расходования энергии, которое будет находить реализацию в передовых технологиях, например, активации процессов в дезинтеграторе.

Процессы тонкого измельчения дискретных скальных минералов в дезинтеграторе являются новыми, пока еще малоизученными подходами к расходованию энергетических ресурсов.

Извлечение металлов из ранее теряемого минерального сырья является прорывным процессом, многократно окупающим затраты на диверсификацию производства.

\section{СПИСОК ЛИТЕРАТУРЫ}

1. Kantemirov V.D. Technologic features of the development of new raw material bases. GIAB. 2014. No. 6. P. 369373.

2. Parker H.M. Reconciliation principles for the mining industry. Mining Techn. 2012. V. 121, no. 3. P. 160 - 176.

3. Franks D.M., Boger D.V., Côte C.M., Mulligan D.R. Sustainable Development Principles for the Disposal of Mining and Mineral Processing Wastes. Resources Policy. 2011. V. 36, no. 2. P. 114-122.

4. Васильева Т.Н. Надежность электрооборудования и систем электроснабжения. Москва: Горячая линия - Телеком, 2015. 152 c.

5. Morkun V., Morkun N., Pikilnyak A. Simulation of the Lamb waves propagation on the plate which contacts with gas containing iron ore pulp in Waveform Revealer toolbox. Metallurgical and Mining Industry. 2014. V. 5. P. 16 - 19.

6. Плащанский Л.А. Оценка эффективности систем электроснабжения с разветвленной структурой для шахт высокой производительности. Вестник высших учебных заведений Черноземья. 2015. № 2. С. 11-13.

7. Morkun V., Semerikov S., Hryshchenko S. Environmental competency of future mining engineers. Metallurgical and Mining Industry. 2014. No. 4. P. 4-7.

8. Klyatis L.M. Accelerated Reliability and Durability Testing Technology. New Jersey: John Wiley \& Sons, 2012.430 p.

9. Haifeng Wang. Development of Mineral Processing Engineering Education in China University of Mining and Technology. Advances in Computer Science and Engineering. AISC 141. Springer-Verlag, Berlin Heidelberg, 2012. P. $77-83$.

10. Голик В.И. Концепция изменения свойств минералов в дезинтеграторе. Известия Тульского государственного университета. Науки о Земле. 2016. № 1. С. 88-100.

11. Morkun V., Tron, V. Automation of iron ore raw materials beneficiation with the operational recognition of its varieties in process streams. Metallurgical and Mining Industry. 2014. V. 6. P. 4-7.

12. Ustinov D.A. Synthesis Procedure of the Power Supply Systems Topology at Mineral Resource Enterprises bastd on Logical-Probabilistic Assessments. International Journal Applied Engineering Research. 2016. V. 11, no. 9. P. $6402-6406$.

13. Aparin E.L. High-quality units of ignition and flame control - condition of reliable and safe work of boiler plants. Energosberezhenie. 2016. No. 3. P. 44-47.

14. Голик В.И., Комащенко В.И. Отходы обогащения железистых кварцитов как сырье для доизвлечения металлов и использования в качестве закладочных смесей. Горный журнал. 2017. № 3. C. 43-47. doi: 10.17580/ GZH.2017.03.08.

15. Голик В.И. Концепция изменения свойств минералов в дезинтеграторе. Известия Тульского государственного университета. Науки о Земле. 2016. № 1. С. 88-100.

16. Лукуткин Б.В. Повышение надежности и качества электроснабжения потребителей. Известия Томского политехнического университета. Инжиниринг георесурсов. 2013. Т. 306, № 1. С. 144-148.

17. Shchepetkov N.I. Energy-efficient approach to room and urban habitat lighting. Energosberezhenie. 2016. No. 3. P. 20-24.

18. Басов В.В., Риб С.В., Фрянов В.Н. Исследование характера деформирования эквивалентного материала для тестирования численной модели прогноза устойчивости сопряжений горных выработок. Известия ТулГУ. Науки о Земле. 2017. Вып. 2. С. 134-145. 
19. Liu H., Han J., Ge S., Wang C. Improved analytical method of power supply capability on distribution systems. International Journal of Electrical Power and Energy Systems. 2014. V. 63. P. 97-104.

20. Васильев Б.Ю. Электропривод. Энергетика электропривода. Москва: Солон-Пресс, 2015. 267 с.

21. Hughes A., Drury B. Electric Motors and Drives. Newnes, 2013. 440 p.

22. Stoffel B. Assessing the Energy Efficiency of Pumps and Pump Units. Elsevier, 2015. 158 p.

Стаття надійшла до редакції 03.11.17

\section{REFERENCES}

1. Kantemirov, V. D. (2014). Technologic features of the development of new raw material bases. GIAB, 6, 369-373.

2. Parker, H. M. (2012). Reconciliation principles for the mining industry. Mining Techn., 121(3), 160-176.

3. Franks, D. M., Boger, D. V., Côte, C. M., Mulligan, D. R. (2011). Sustainable Development Principles for the Disposal of Mining and Mineral Processing Wastes. Resources Policy, 36(2), 114-122.

4. Vasil'eva, T. N. (2015). Reliability of electrical equipment and power supply systems. Moskva: Hot line - Telecom [in Russian].

5. Morkun, V., Morkun, N., Pikilnya, A. (2014). Simulation of the Lamb waves propagation on the plate which contacts with gas containing iron ore pulp in Waveform Revealer toolbox. Metallurgical and Mining Industry, 5, 16-19.

6. Plashchanskij, L. A. (2015). Ocenka ehffektivnosti sistem ehlektrosnabzheniya s razvetvlennoj strukturoj dlya shaht vysokoj proizvoditel'nosti. Vestnik vysshih uchebnyh zavedenij Chernozem'ya (Neres of higher educational institutions of Black Soil), 2, 11-13 [in Russian].

7. Morkun, V., Semerikov, S., Hryshchenko, S. (2014). Environmental competency of future mining engineers. Metallurgical and Mining Industry, 4, 4-7.

8. Klyatis, L. M. (2012). Accelerated Reliability and Durability Testing Technology. New Jersey: John Wiley \& Sons.

9. Haifeng, Wang, Yaqun, He, Chenlong, Duan, Yuemin, Zhao, Youjun, Tao, Cuiling, Ye. (2012). Development of Mineral Processing Engineering Education in China University of Mining and Technology. Advances in Computer Science and Engineering. AISC 141. Springer-Verlag, Berlin Heidelberg, 77-83.

10. Golik, V. I. (2016). Koncepciya izmeneniya svojstv mineralov v dezintegratore. Izvestiya Tul'skogo gosudarstvennogo universiteta. Nauki o Zemle ("Izvestija Tulskogo gosudarstvennogo universiteta" ("Izvestija TulGU"), 1, 88-100 [in Russian].

11. Morkun, V., Tron, V. (2014). Automation of iron ore raw materials beneficiation with the operational recognition of its varieties in process streams. Metallurgical and Mining Industry, 6, 4-7.

12. Ustinov, D. A., Baburin, S. V. (2016). Synthesis Procedure of the Power Supply Systems Topology at Mineral Resource Enterprises bastd on Logical-Probabilistic Assessments. International Journal Applied Engineering Research, 11(9), $6402-6406$.

13. Aparin, E. L. (2016). High-quality units of ignition and flame control - condition of reliable and safe work of boiler plants. Energosberezhenie, 3, 44-47.

14. Golik, V. I., Komachshenko, V. I. (2017). Waste of ferruginous quartzite enrichment as a raw material for metal recovery and use as laying mixtures. Gornyj zhurnal (Mining Journal), 3, 43-47. doi: 10.17580/GZH.2017.03.08 [in Russian].

15. Golik, V. I. (2016). Koncepciya izmeneniya svojstv mineralov v dezintegratore. Izvestiya Tul'skogo gosudarstvennogo universiteta. ("Izvestija Tulskogo gosudarstvennogo universiteta" ("Izvestija TulGU"). Nauki o Zemle, 1, 88-100 [in Russian].

16. Lukutkin, B. V. (2013). Povyshenie nadezhnosti i kachestva ehlektrosnabzheniya potrebitelej. Izvestiya Tomskogo politekhnicheskogo universiteta. Inzhiniring georesursov (Bulletin of the Tomsk Polytechnic University. Geo Assets Engineering), 306(1), 144-148 [in Russian].

17. Shchepetkov, N. I. (2016). Energy-efficient approach to room and urban habitat lighting. Energosberezhenie, 3, $20-24$.

18. Basov, V. V., Reeb, S. V., Fryanov, V. N. (2017). The study of the nature of deformation of an equivalent material to test the numerical model for prediction of stability of mates of mine workings. Izvestiya Tul GU. Earth science, 2, 134-145.

19. Liu, H., Han, J., Ge, S., Wang, C. (2014). Improved analytical method of power supply capability on distribution systems. International Journal of Electrical Power and Energy Systems, 63, 97-104.

20. Vasil'ev, B. Yu. (2015). The electric drive. Power of the electric drive. Moskva: Solon-Press [in Russian]

21. Hughes, A., Drury, B. (2013). Electric Motors and Drives. Newnes.

22. Stoffel, B. (2015). Assessing the Energy Efficiency of Pumps and Pump Units. Elsevier.

Received 03.11.17 


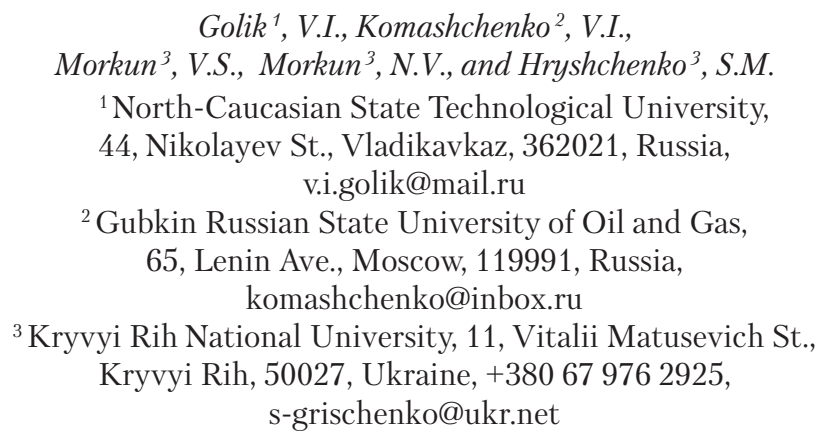

\title{
ENERGY SAVING IN MINING PRODUCTION
}

Introduction. Mining is a rather energy-intensive industry because of severe conditions of technological processes with energy consumption optimized by engineering modernization, for instance, by producing settable mixes and processing their components to obtain the required size and activity.

Problem Statement. Reducing energy consumption while escalating production, energy efficiency of technological processes and cost reduction in energy supply are relevant problems for mining industry, which determine the competitiveness of a mining corporation.

Purpose. The research aims at determining the effect of disintegration and increased activity of ore minerals on energy consumption by mining enterprise.

Materials and Methods. Efficiency of mechanical activation is conditioned by difference in strength of concrete based on basic and activating binding materials. Efficient combination of technologies has been found as optimal solution taking into consideration variable factors, including energy consumption. The range of optimal values of binding materials has been found by solving the equations describing the obtained regularities.

Results. The research presents the results of industrial experiment aiming at replacing the binding components of concrete mixes by the activated blast-furnace slag. The quantitative indicators and regularities of electric energy consumption necessary to activate components of settable mixes have been determined. The obtained data have been used to simulate mix design at one of Norilsk enterprises. The general regularities of mechanical activation efficiency have been established and a concept and an algorithm of efficient energy consumption while activating mining production wastes have been formulated.

Conclusions. For the demographic factors of the development, the mining industry will increase energy-intensity of industrial processes. When transiting to underground deposit mining, production of settable mixes will result in increased energy consumption. Efficient energy consumption in energy-intensive industrial processes becomes especially important. In the specified conditions, optimized energy consumption facilitates the recovery of costs for mining diversification.

Keywords: energy efficiency, energy saving, mining production, disintegrator, and activation.

\author{
B.I. Голік ${ }^{1}$, В.I. Комащенко ${ }^{2}$, \\ В.С. Моркун ${ }^{3}$, Н.В. Моркун ${ }^{3}$, С.М. Грищенко \\ ${ }^{1}$ Північно-Кавказький державний технологічний університет, \\ вул. Ніколаєва, 44, Владикавказ, 362021, Росія, \\ v.i.golik@mail.ru \\ ${ }^{2}$ Російський державний університет нафти та газу \\ (національний дослідний університет) імені I.M. Губкіна, \\ корп. 1, буд. 65, просп. Ленінський, Москва, 119991, Росія, \\ komashchenko@inbox.ru \\ ${ }^{3}$ ДВНЗ «Криворізький національний університет», \\ вул. Віталія Матусевича, 11, Кривий Ріг, 50027, Україна, \\ +38067976 2925, s-grischenko@ukr.net
}

\section{ДО ПРОБЛЕМИ ЕНЕРГОЗБЕРЕЖЕННЯ В ГІРНИЧОМУ ВИРОБНИЦТВІ}

Вступ. Гірська промисловість є досить енергоємнісною галуззю через напруженість режимів технологічних процесів, в яких енерговитрати оптимізуються шляхом технічної модернізації, наприклад, процесу виготовлення твердіючих сумішей з обробкою компонентів суміші до необхідного розміру часток та їх активності. 
Проблематика. Мінімізація енергозатрат при збільшенні обсягу виробництва, підвищення енергоефективності технологічних процесів та зниження затрат на енергозабезпечення формує самостійну проблему гірничої галузі, що визначає конкурентоздатність гірничого підприємства.

Мета. Визначення впливу процесів дезінтеграції та підвищення активності рудних матеріалів на енергоспоживання гірничого підприємства.

Матеріали й методи. Ефективність механоактивації визначається різницею міцності бетонів, виготовлених на основі базових та активованих в'яжучих компонентів. Раціональна комбінація технологій знаходиться як оптимум рішення з урахуванням змінних факторів, зокрема й енерговитрат. Область оптимальних значень в'яжучих компонентів знаходиться спільним розв'язуванням рівнянь, які описують отримані закономірності.

Результати. Наведено результати промислового експерименту з заміни в'яжучих компонентів бетонних сумішей активованими доменними шлаками. Визначені кількісні значення та закономірності витрат електроенергії на активацію компонентів твердіючих сумішей. Отримані дані використані для моделювання процесів підготовки суміші в умовах одного з підприємств Норильська. Встановлено загальні закономірності корисної дії механічної активації. Сформульовано концепцію та алгоритм раціоналізації енергокористування в процесах активації відходів гірничої промисловості.

Висновки. У зв'язку з демографічними факторами розвитку гірська промисловість буде збільшувати енергоємність виробничих процесів. При переході на розробку родовищ підземним способом витрати енергії на виготовлення твердіючих сумішей зростають. Особливої актуальності набуває напрямок корисної витрати енергії в електроємнісних процесах. Оптимізація витрат енергії у визначених умовах сприяє компенсації витрат на диверсифікацію гірської промисловості.

Ключові слова: енергоефективність, енергозбереження, гірська промисловість, дезінтегратор, активація. 